\title{
A baseline study using Plantwise information to assess the contribution of extension services to the uptake of augmentative biological control in selected low- to lower- middle- income countries
}

\author{
Julien Dougoud · Matthew J. W. Cock · Steve Edgington • Ulrich Kuhlmann
}

Received: 24 November 2016/ Accepted: 1 June 2017/Published online: 21 June 2017

(C) The Author(s) 2017. This article is an open access publication

\begin{abstract}
The uptake of augmentative biological control agents (BCAs) is still limited, particularly in many low- to lower- middle- income countries. This study focuses on factors that affect the uptake of BCAs for arthropod pests by national extension partners (NEPs) in Plantwise-an agricultural development programme facilitating the establishment of plant clinics where farmers can obtain diagnosis and plant health advice. Using data generated by NEPs, BCA recommendations in extension material and given by extension workers in Ghana, Kenya, Zambia, India, Nepal and Pakistan were analysed. The rate of BCA recommendation ranged from 13.0 (Zambia) to $61.1 \%$ (India) in extension materials and from 0.0 (Zambia) to $18.2 \%$ (India) in recommendations given by extension workers. Knowledge, availability and price were identified as the main factors affecting the uptake of BCAs by NEPs. This baseline study gives novel
\end{abstract}

Handling Editor: Russell Messing.

J. Dougoud · U. Kuhlmann ( $\square)$

CABI, Rue des Grillons 1, 2800 Delémont, Switzerland

e-mail: u.kuhlmann@cabi.org

J. Dougoud

e-mail: j.dougoud@cabi.org

M. J. W. Cock · S. Edgington

CABI, Bakeham Lane, Egham, Surrey TW20 9TY, UK

e-mail: m.cock@cabi.org

S. Edgington

e-mail: s.edgington@cabi.org insight into the potential of NEPs to facilitate the use of BCAs.

Keywords Africa $\cdot$ Asia $\cdot$ Plant clinics · Technology dissemination $\cdot$ Pest management $\cdot$ Biological control agents

\section{Introduction}

Biological control agents (BCAs) are an important component of an integrated pest management (IPM) approach for the control of arthropod pests, weeds and diseases (Cock et al. 2012; Lewis et al. 1997). BCAs are living organisms which can reduce the population density of other, harmful living organisms. They include macrobials (e.g. insect-parasitic nematodes, predatory and parasitic arthropods) and microbials (e.g. fungal, bacterial and viral pathogens) (Harper 2013; van Lenteren 2012; Sundh and Goettel 2013). At the farm level, biological control is used in two main ways: conservation biological control through measures that aim at increasing indigenous natural enemy populations, and augmentative biological control by the deliberate release of cultured BCAs (Bale et al. 2008; Hoeschle-Zeledon et al. 2013). This paper focuses on the latter approach.

Since the 1990s the use of BCAs in augmentative biological control has been increasing, particularly in developed countries (Thakore 2006). Concerns about 
the toxicity of synthetic pesticides to humans and the environment and issues of resistance to pesticides are making the use of BCAs increasingly attractive (Abhilash and Singh 2009; Chandler et al. 2011; Glare et al. 2012). Worldwide, the number of macrobials available for augmentative biocontrol of arthropods is estimated to be around 350 species, targeting over 100 pest species (Cock et al. 2010; van Lenteren 2012; van Lenteren et al. 2017). Over 200 registered microbial products to control arthropod pests of crops, based on about 40 species or subspecies, have been inventoried (Hoeschle-Zeledon et al. 2013; Koul 2011; van Lenteren et al. 2017). BCAs' share of the global crop protection market is still small (about 5\%). However, it is growing rapidly (Glare et al. 2012; Harper 2013; Olson 2015), although Africa is being left behind (Olson 2015).

In order for the use of BCAs to achieve its potential in low- to lower- middle- income countries, several steps need to be addressed by regulatory, research and extension agencies and agri-input suppliers. Before potential BCAs can be used in agriculture, they need to be evaluated and registered. Then, their use as part of an IPM strategy needs to be formulated and incorporated into extension pest management advice. Agriinput suppliers need to make the BCAs available when and where needed at an affordable price and extension workers need to recommend these BCAs to farmers and explain how to use them. Finally farmers need to use BCAs in their farms, confident that they will have the required effect. In this study we examine the contribution of national extension partners (NEPs) in the agricultural development programme Plantwise (http://www.plantwise.org) to the uptake of BCAs and how this is affected by several of these constraints, using information and data generated by NEPs.

Plantwise is a global initiative led by CABI to increase food security and improve rural livelihoods by reducing crop losses. Plantwise works with national partners, usually state-run extension services, to establish networks of local plant clinics, run by trained extension staff (referred to here as plant doctors), where farmers can obtain a pest diagnosis and practical plant health advice on written 'prescription forms' (Danielsen and Matsiko 2016; Plantwise 2016b). Plant doctors are supported by resources which include factsheets, pest management guides and diagnostic tools, available through the open access online and off-line Plantwise knowledge bank (http://
www.plantwise.org/KnowledgeBank/). In 2016, the programme was operational in 34 countries across Asia, Africa, and the Americas. By the end of 2016, the programme had facilitated the establishment of over 2000 plant clinics, had directly reached over two million farmers and had coordinated the development of over 2400 factsheets and pest management decision guides (PMDGs). The implementation of IPM, and therefore the use of BCAs, is being promoted through the Plantwise programme to sustainably strengthen national plant health systems in developing countries.

We analysed the national lists of registered pesticides, the PMDGs produced by national partners and data on plant health problems diagnosed at plant clinics. PMDGs are extension materials developed in Plantwise countries by national experts following the concept of green and yellow lists, first developed and introduced by the Commission on 'Guidelines for Integrated Production' of the International Organization for Biological Control (IOBC 2016). Based on a traffic light system, they contain a selection of the most appropriate preventive and direct control methods and are quick and easy-to-use guides for field use by plant doctors. Data on plant health problems diagnosed at plant clinics were obtained from an online data management tool, Plantwise Online Management System (POMS). Plant doctors record each pest diagnosis and associated recommendations on a standard prescription form and then upload the records to POMS. This database thus gives an accurate overview of the plant health problems for which farmers seek assistance at plant clinics.

This baseline study investigates factors that may affect the uptake by NEPs of BCAs for augmentative biological control of arthropod pests in selected low to lower middle income countries. We focus on the following questions (i) What BCAs are locally registered? (ii) Are extension materials available to plant doctors, do they include BCAs, and what scope is there to improve this? (iii) What types of pest management advice do plant doctors give, how often do they include BCAs, and what scope is there to improve this?

\section{Materials and methods}

Six countries from the Plantwise programme were selected for our analysis: three African countries (Ghana, Kenya and Zambia) and three Asian countries 
(Pakistan, India (Maharashtra and South-Eastern region only) and Nepal). These countries were selected as they had sufficient plant clinic prescription data to enable relatively in-depth analysis. For each country, the data on plant health problems diagnosed at plant clinics from two to five different administrative regions where Plantwise is active were analysed separately. Those were: Ashanti, Brong Ahafo, Eastern, Northern and Volta in Ghana; Central, Eastern, Nyanza, Rift and Western in Kenya; Central, Eastern, Lusaka and Southern in Zambia; Maharashtra, Puducherry and Tamil Nadu in India; Madhyamanchal, Pashchimanchal and Purwanchal in Nepal; and Punjab and Sindh in Pakistan.

BCAs registered for arthropod pest control in the study countries

Lists of registered BCAs were obtained from the following: Kenya - the Pest Control Product Board (PCPB 2015); Ghana-the Ministry of Food and Agriculture (unpublished); India-the Central Insecticides Board \& Registration Committee (CIBRC 2016a, b); Nepal-the Pesticide Registration and Management Division (PRMD 2015); Pakistan-the Department of Plant Protection (DPP 2016); and Zambia - the Homologa online database (Homologa 2016). Of these countries, only Kenya includes macrobials in their list of registered plant protection products.

\section{Availability of extension material including BCAs}

The total number of nationally produced PMDGs and the number of nationally produced PMDGs for arthropod pests were tabulated for each country. An inventory of BCA recommendations in these nationally produced arthropod pest PMDGs was made and the frequency of BCA recommendations was calculated for each of the six countries.

Most frequently diagnosed arthropod pests in each country, availability of extension material addressing these, and BCAs registered for their control

For each country, data on arthropod pest problems diagnosed at plant clinics for a one year period were downloaded from POMS. This covered 1 July 2015-30 June 2016, except for Nepal, where, due to a lack of data following an earthquake in April 2015, data from the previous year (1 July 2014-30 June 2015) were used. Plant doctors usually use common names or common group names when making a diagnosis, and we have been constrained to follow the same practice. Data were harmonised where different names had been used by plant doctors for a single pest or pest group, e.g. 'aphids' and 'black aphids' were combined as 'aphids', and 'borer' insects were grouped by host crop information, e.g. 'borers' on maize were grouped together with 'maize stem borers' and 'maize stalk borer'. At this time, none of these prescription records have yet been checked by the national validation committees of the study countries. However, since misdiagnosis is expected to be least likely for the most common pests, we do not anticipate that this will significantly affect our results, which focus on the pests most frequently diagnosed at plant clinics.

For the top ten arthropod pests, i.e., those diagnosed at plant clinics most frequently in each country, we assessed the availability of a corresponding nationally produced PMDG, the inclusion of BCA recommendations in that PMDG, whether BCAs have been nationally registered for each pest, and whether BCAs have been registered or are available elsewhere for the same or similar pests. Host range data of BCA products were obtained from the lists of registered pesticides for each country, from product labels or via direct contact with manufacturers. Data on BCAs commercially available elsewhere were gathered from van Lenteren (2012) for macrobials and from Koul (2011) and Hoeschle-Zeledon et al. (2013) for microbials.

BCA recommendations made by plant doctors

The plant doctors categorise their recommendations by ticking predefined boxes on the prescription form. They are also given a free text box to give additional information regarding the recommendation. The frequency of control option check boxes 'cultural' and 'insecticide/acaricide' was counted. BCA recommendations were counted through a word search in the free text section of recommendations, using both the scientific names and trade names of locally registered BCAs (including misspellings).

For the top ten arthropod pests in each country, we tabulated those pests for which the nationally produced PMDG includes a BCA recommendation. For 
each of those pests, we tabulated the number of prescription records for that pest and the percentage of the prescription records which included a recommendation for one of the BCAs recommended in the PMDG.

Only regularly active plant doctors with at least 20 prescription records over the study period were included in an assessment of the propensity of plant doctors to make BCA recommendations. Prescription sheets signed by two plant doctors were not included in this assessment because the recommendations they contain could not be attributed to a single plant doctor. The percentage of prescription records including a BCA was calculated for each plant doctor.

\section{Synthesis}

In order to show the relative importance of different factors in restricting BCA recommendations, we compiled, for the top ten arthropod pests in each country, the availability of nationally produced PMDGs, the proportion of prescription records with a BCA recommended by plant doctors, the proportion of prescription records for which nationally produced PMDGs have a BCA recommendation, the proportion of prescription records for which a suitable $\mathrm{BCA}$ is presumably available in the country and the proportion of prescription records for which a BCA is available in another country. BCAs were considered to be available at a national level when they were registered in the country or, in the case of macrobials, when they were recommended in PMDGs (except in Kenya where macrobials are registered).

\section{Results}

BCAs registered for arthropod pest control in the study countries

The number of registered BCAs varied considerably among the study countries (Table 1). At the time of our analysis (September 2016), Kenya and India had more species registered than the other countries, although for Kenya this included macrobials. Bacillus thuringiensis Berliner (Bacilliales: Bacillaceae) and Metarhizium anisopliae (Metschnikoff) Sorokin (Hypocreales: Clavicipitaceae) were both registered in five of the six countries.
Availability of extension material including BCAs

On average, $44.7 \%$ of the PMDGs were written for arthropod pests. The number of nationally produced PMDGs written for arthropod pests ranged from 14 in Nepal to 28 in Kenya (Table 2). Most of the other PMDGs addressed diseases and only a few addressed physiological disorders and weeds. BCAs were frequently included in nationally produced arthropod PMDGs in India (61.1\%) and Nepal (57.1\%), but only rarely so in Zambia (13.0\%). Macrobials and microbials were roughly equally represented among BCA recommendations included in nationally produced PMDGs.

Most frequently diagnosed arthropod pests in each country, availability of extension material covering these and BCAs registered for their control

A total of 45,757 plant clinic prescriptions were analysed of which 16,930 (37.0\%) were for arthropod pests. Nationally produced PMDGs were available for most or all of the top ten pests in Kenya and Zambia but India had PMDGs for only four of the top ten pests (Table 3). The available PMDGs did not always include microbials that were locally registered, e.g. Lecanicillium lecanii (Zimmermann) Zare \& W. Gams (Hypocreales: Clavicipitaceae) for control of thrips in Kenya and Nepal, B. thuringiensis for control of the non-borer lepidopterans in Kenya and India, and M. anisopliae and Beauveria bassiana (BalsamoCrivelli) Vuillemin (Hypocreales: Ophiocordypitaceae) for control of a wide range of pests in Kenya, India and Nepal. In Ghana, Pakistan and Zambia, microbials were registered for 0,1 and 3 of the top ten arthropod pests in those countries, respectively. The range of macrobials that were locally available is unknown, except for Kenya, where registration is required (and therefore data are available). Globally, BCAs have been commercialised for control of the great majority of the top ten pests diagnosed at plant clinics, except for several important cocoa pests present in Ghana.

BCA recommendations by extension workers

Plant doctors usually gave recommendations with mixed strategies (e.g. chemical + cultural). Overall, 
Table 1 Registered biological control agents for arthropod pests in study countries

\begin{tabular}{|c|c|c|c|}
\hline Country & Registered biological control agent & Type of biological control agent & Primary target pests \\
\hline \multirow[t]{2}{*}{ Ghana } & Bacillus thuringiensis $+P$. rapae $\mathrm{GV}^{\mathrm{a}}$ & Bacterial + viral pathogen & Lepidoptera \\
\hline & Metarhizium anisopliae & Fungal pathogen & Mealybugs \\
\hline \multirow[t]{19}{*}{ Kenya } & Amblyseius californicus & Predatory mite & Mites \\
\hline & Amblyseius cucumeris & Predatory mite & Mites, thrips \\
\hline & Amblyseius swirskii & Predatory mite & Whiteflies \\
\hline & Hypoaspis miles & Predatory mite & Thrips \\
\hline & Phytoseilus persimilis & Predatory mite & Mites \\
\hline & Aphidius transcaspinus & Parasitoid wasp & Aphids \\
\hline & Coccidoxenoides perminutus & Parasitoid wasp & Mealybugs \\
\hline & Diglyhus isaea & Parasitoid wasp & Diptera leaf miners \\
\hline & Encarsia formosa & Parasitoid wasp & Whiteflies \\
\hline & Eretmocerus eremicus & Parasitoid wasp & Whiteflies \\
\hline & Steinernema carpocapsae & Insect-parasitic nematode & Lepidoptera \\
\hline & Steinernema feltiae & Insect-parasitic nematode & Soil-pupating pests \\
\hline & Bacillus thuringiensis var. aizawai & Bacterial pathogen & Lepidoptera \\
\hline & Bacillus thuringiensis var. kurstaki & Bacterial pathogen & Lepidoptera \\
\hline & Paecilomyces fumosoroseus & Fungal pathogen & Aphids, whiteflies \\
\hline & Beauveria bassiana & Fungal pathogen & Wide range of pests \\
\hline & Lecanicillium lecanii & Fungal pathogen & Aphids, whiteflies \\
\hline & Metarhizium anisopliae & Fungal pathogen & Mites \\
\hline & NPV of Helicoverpa armigera $^{\mathrm{b}}$ & Viral pathogen & Helicoverpa armigera \\
\hline \multirow[t]{2}{*}{ Zambia } & Bacillus thuringiensis & Bacterial pathogen & Lepidoptera \\
\hline & Metarhizium anisopliae & Fungal pathogen & Orthoptera \\
\hline \multirow[t]{9}{*}{ India } & Bacillus thuringiensis var. galleriae & Bacterial pathogen & Lepidoptera \\
\hline & Bacillus thuringiensis var. kurstaki & Bacterial pathogen & Lepidoptera \\
\hline & Photorhabdus luminescens & Bacterial pathogen & Not explicit \\
\hline & Beauveria bassiana & Fungal pathogen & Lepidoptera \\
\hline & Hirsutella thompsonii & Fungal pathogen & Mites \\
\hline & Lecanicillium lecanii & Fungal pathogen & Mealybugs, whiteflies \\
\hline & Metarhizium anisopliae & Fungal pathogen & Leucinodes orbonalis, Nilaparvata lungens \\
\hline & NPV of Helicoverpa armigera $^{\mathrm{b}}$ & Viral pathogen & Helicoverpa armigera \\
\hline & NPV of Spodoptera litura ${ }^{\mathrm{b}}$ & Viral pathogen & Spodoptera litura \\
\hline \multirow[t]{3}{*}{ Nepal } & Beauveria bassiana & Fungal pathogen & Wide range of pests \\
\hline & Lecanicillium lecanii & Fungal pathogen & Wide range of pests \\
\hline & Metarhizium anisopliae & Fungal pathogen & Wide range of pests \\
\hline \multirow[t]{2}{*}{ Pakistan } & Bacillus thuringiensis & Bacterial pathogen & Lepidoptera \\
\hline & NPV of Helicoverpa armigera ${ }^{\mathrm{b}}$ & Viral pathogen & Helicoverpa armigera \\
\hline
\end{tabular}

a Granulosis virus

b Nuclear polyhedrosis virus

when looking at the recommendations for all arthropod pests, the popularity of different management types varied considerably among the study countries (Fig. 1). BCAs were most frequently recommended by plant doctors in India (18.2\% of the recommendations contained a BCA). BCA recommendations were much less frequent in Nepal (6.2\%), Ghana (4.9\%) and Kenya (3.6\%), almost absent in Pakistan (0.7\%), and 
Table 2 Analysis of recommendations of biological control agents (BCAs) in nationally produced arthropod pest management decision guides (PMDGs) for each study country

\begin{tabular}{llll}
\hline Country & $\begin{array}{l}\text { Number of PMDGs } \\
\text { available in 2016 }\end{array}$ & $\begin{array}{l}\text { Number of PMDGs } \\
\text { on arthropod pests }\end{array}$ & $\begin{array}{l}\text { \% PMDGs on arthropod pests with } \\
\text { BCA recommendations }\end{array}$ \\
\hline Ghana & 30 & 15 & 33.3 \\
Kenya & 68 & 28 & 28.6 \\
Zambia & 58 & 23 & 13.0 \\
India & 25 & 18 & 61.1 \\
Nepal & 24 & 14 & 57.1 \\
Pakistan & 50 & 15 & 26.7 \\
\hline
\end{tabular}

totally absent in Zambia. The majority of prescription forms included a chemical pesticide as part of the recommendation. Cultural control was heavily recommended in all countries except Pakistan, where plant doctors mainly recommended pesticides.

BCA recommendations included in nationally produced PMDGs were not always passed on to farmers by plant doctors (Table 4). In Ghana and Zambia, none of the BCAs that were included within PMDGs were subsequently recommended to farmers. BCAs included in nationally produced PMDGs were rarely recommended by plant doctors in Kenya and Pakistan, although Trichogramma spp. was included for the control of sugarcane borers in $10.6 \%$ of cases in Pakistan. In India and Nepal, the recommendations of BCAs by plant doctors were more frequent: $18.6 \%$ and $38.3 \%$ respectively of the recommendations contained a BCA from the corresponding nationally produced PMDG. In India, the rates varied depending on the pest, ranging from 0 to $47.6 \%$.

The propensity of plant doctors to recommend BCAs varied considerably among study countries (Table 5). Many plant doctors made no BCA recommendations, but some recommended BCAs frequently. In all countries, most of the BCA recommendations were made by a limited number of plant doctors.

\section{Synthesis}

Figure 2 gives an overview of the availability of nationally produced PMDGs, of BCA recommendations given by plant doctors, of BCA recommendation included in nationally produced PMDGs and of the availability of BCAs for the ten pests most frequently diagnosed at plant clinics. Working through one example will make the implications clearer. In Pakistan, only $0.9 \%$ of prescription records for these pests had a BCA recommendation. There were nationally produced PMDGs available for $68.1 \%$ of these prescription records, $16.9 \%$ of which contained a BCA. Thus, the percentage of prescription records with a BCA recommendation could be increased from 0.9 to $16.9 \%$ if the plant doctors always included a BCA recommendation when there was one in the nationally produced PMDGs. This percentage could be increased to $37.6 \%$ if all appropriately registered BCAs appeared in the relevant PMDGs, and could be further increased to $96.5 \%$ if selected BCAs available outside Pakistan were also registered and made available in Pakistan.

\section{Discussion}

We set out to investigate how extension services, and in particular the Plantwise programme, can contribute to the uptake of BCAs by farmers, and how this may be affected by various factors, notably the availability of registered biocontrol agents, the availability of extension material containing relevant biological control strategies and the extension workers' knowledge of biological control. Thus, for any particular pest-crop combination there may or may not be a suitable BCA available somewhere in the world, but it may not be registered in a country, it may not be available or affordable where needed in that country, it might not be included in information for extension staff (PMDGs for plant doctors), extension staff (plant doctors) may not recommend BCAs, or farmers may not use BCAs when given a recommendation to do so. Our analysis summarised in Fig. 2 examines the relative importance of some of these barriers, particularly for those steps in this chain where the Plantwise programme is playing a role to promote BCAs and IPM. 
Table 3 The arthropod pests most commonly diagnosed at plant clinics for each study country, the availability of nationally produced pest management decision guides (PMDGs) and information on biological control agents (BCAs)

\begin{tabular}{llllll}
\hline $\begin{array}{l}\text { Country (number of } \\
\text { prescription records for } \\
\begin{array}{l}\text { arthropod pests) Top } \\
\text { ten pests }\end{array}\end{array}$ & $\begin{array}{l}\% \text { of prescription } \\
\text { records }( \pm \text { SE) for } \\
\text { each pest }\end{array}$ & $\begin{array}{l}\text { PMDG } \\
\text { available for } \\
\text { each pest }\end{array}$ & $\begin{array}{l}\text { BCA included } \\
\text { in PMDG for } \\
\text { pest }\end{array}$ & $\begin{array}{l}\text { BCA registered for } \\
\text { pest in study } \\
\text { country }\end{array}$ & $\begin{array}{l}\text { Suitable BCA } \\
\text { commercially available in } \\
\text { another country }\end{array}$ \\
\hline
\end{tabular}

Ghana $(\mathrm{n}=3788)$

Cocoa stink bugs

Termites

Cocoa stem borers

Cocoa mirids

Aphids

Maize stem borers

Fruit flies

Flea beetles

Whiteflies

Maize weevils

Minor pests

Diagnosis not explicit

Kenya ( $\mathrm{n}=3932$ )

Aphids

Maize stalk borers

Tuta absoluta

Thrips

Whiteflies

Scales

Fruit flies

Bean flies

Leaf miners

Diamondback moths

Minor pests

Diagnosis not explicit

Zambia ( $\mathrm{n}=486$ )

Aphids

Grasshoppers, crickets

Termites

Diamondback moths

Leaf miners

Tuta absoluta

Maize stalk borers

American bollworms

Fruit flies

Whiteflies

Minor pests

Diagnosis not explicit

India $(\mathrm{n}=2221)$

Thrips

$$
\begin{array}{r}
13.3 \pm 3.8 \\
11.0 \pm 2.3 \\
10.5 \pm 3.3 \\
10.4 \pm 2.9 \\
4.3 \pm 0.8 \\
4.1 \pm 0.6 \\
4.0 \pm 0.4 \\
2.9 \pm 1.9 \\
2.8 \pm 0.9 \\
2.2 \pm 3.7 \\
18.9 \pm 4.1 \\
15.6 \pm 5.1
\end{array}
$$

$23.8 \pm 3.1$

$11.2 \pm 3.2$

$5.8 \pm 1.6$

$5.2 \pm 1.2$

$5.2 \pm 0.9$

$4.2 \pm 0.9$

$3.6 \pm 0.7$

$2.8 \pm 1.1$

$2.7 \pm 1.3$

$2.4 \pm 0.5$

$25.3 \pm 3.1$

$8.3 \pm 3.1$

$17.1 \pm 3.7$

$9.2 \pm 2.9$

$8.6 \pm 3.8$

$7.7 \pm 2.0$

$7.1 \pm 2.0$

$6.4 \pm 2.7$

$6.2 \pm 1.2$

$4.7 \pm 1.3$

$3.0 \pm 1.9$

$3.0 \pm 0.7$

$20.6 \pm 3.3$

$6.4 \pm 5.4$
$+$

$-$

$+$

$+$

$+$

$-$

$+$

$+$

$+$

$+$

$+$
$-$

$-$

$-$

$-$

$-$

$-$

$+$

$-$

$+$

$-$

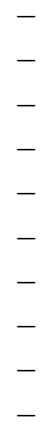

$\begin{array}{llll}+ & + & + & + \\ + & - & - & + \\ + & - & - & + \\ + & - & + & + \\ + & + & + & + \\ + & - & - & + \\ + & - & - & + \\ + & - & + & - \\ + & - & + & + \\ + & - & & +\end{array}$


Table 3 continued

\begin{tabular}{|c|c|c|c|c|c|}
\hline $\begin{array}{l}\text { Country (number of } \\
\text { prescription records for } \\
\text { arthropod pests) Top } \\
\text { ten pests }\end{array}$ & $\begin{array}{l}\% \text { of prescription } \\
\text { records }( \pm \mathrm{SE}) \text { for } \\
\text { each pest }\end{array}$ & $\begin{array}{l}\text { PMDG } \\
\text { available for } \\
\text { each pest }\end{array}$ & $\begin{array}{l}\text { BCA included } \\
\text { in PMDG for } \\
\text { pest }\end{array}$ & $\begin{array}{l}\text { BCA registered for } \\
\text { pest in study } \\
\text { country }^{\text {a }}\end{array}$ & $\begin{array}{l}\text { Suitable BCA } \\
\text { commercially available in } \\
\text { another country }\end{array}$ \\
\hline Rice leaf folders & $8.9 \pm 5.3$ & + & + & + & + \\
\hline Legume pod borers & $8.8 \pm 3.5$ & + & + & + & + \\
\hline Green semiloopers & $5.8 \pm 3.6$ & - & - & + & + \\
\hline Whiteflies & $5.2 \pm 2.5$ & - & - & + & + \\
\hline Jassids & $5.0 \pm 2.1$ & - & - & - & + \\
\hline Aphids & $4.6 \pm 0.7$ & - & - & - & + \\
\hline Tobacco caterpillars & $4.6 \pm 0.4$ & + & + & + & + \\
\hline Eggplant borers & $3.8 \pm 0.7$ & + & + & + & + \\
\hline Rice stem borers & $2.6 \pm 1.6$ & - & - & + & + \\
\hline Minor pests & $20.9 \pm 2.9$ & & & & \\
\hline Diagnosis not explicit & $17 \pm 4.2$ & & & & \\
\hline \multicolumn{6}{|l|}{ Nepal $(\mathrm{n}=586)$} \\
\hline Fruit flies & $16.6 \pm 8.5$ & + & - & + & + \\
\hline Aphids & $10.8 \pm 4.7$ & - & - & + & + \\
\hline Banana weevils & $9.3 \pm 6.7$ & + & - & - & + \\
\hline Rice stem borers & $8.6 \pm 3.4$ & + & + & + & + \\
\hline Red ants & $3.1 \pm 1.6$ & - & - & + & + \\
\hline Thrips & $2.4 \pm 1.7$ & - & - & + & + \\
\hline White grubs & $2.4 \pm 1.0$ & + & + & + & + \\
\hline Eggplant borers & $2.4 \pm 1.2$ & + & + & + & + \\
\hline Leaf miners & $2.0 \pm 1.0$ & + & - & + & + \\
\hline Helicoverpa spp. & $1.8 \pm 1.2$ & - & - & + & + \\
\hline Minor pests & $13.9 \pm 1.7$ & & & & \\
\hline Diagnosis not explicit & $26.7 \pm 26.7$ & & & & \\
\hline \multicolumn{6}{|l|}{ Pakistan $(\mathrm{n}=5935)$} \\
\hline Armyworm & $14.5 \pm 6.8$ & + & - & + & + \\
\hline Whiteflies & $14.4 \pm 3.0$ & + & - & - & + \\
\hline Jassids & $11.1 \pm 0.7$ & - & - & - & + \\
\hline Thrips & $8.9 \pm 3.3$ & - & - & - & + \\
\hline Aphids & $7.0 \pm 3.6$ & + & - & - & + \\
\hline Sugarcane stem borers & $3.3 \pm 1.1$ & + & + & - & + \\
\hline Pink bollworms & $3.2 \pm 5.7$ & + & + & - & + \\
\hline Maize stem borers & $3.1 \pm 1.6$ & + & + & - & + \\
\hline Shootflies & $2.4 \pm 1.2$ & - & - & - & - \\
\hline Fruit flies & $2.2 \pm 1.1$ & + & + & - & + \\
\hline Minor pests & $11.9 \pm 9.1$ & & & & \\
\hline Diagnosis not explicit & $17.8 \pm 7.3$ & & & & \\
\hline
\end{tabular}

${ }^{a}$ Macrobials are only required to be registered in Kenya

Our analysis was based on data on plant health problems diagnosed at the plant clinics. Hence, some common plant health problems may be underrepresented because farmers may feel they already know how to manage them and do not visit the plant clinic to seek help. Conversely, some emerging plant health problems, such as Tuta absoluta Meyrick (Lepidoptera: Gelechiidae), may be overrepresented. 

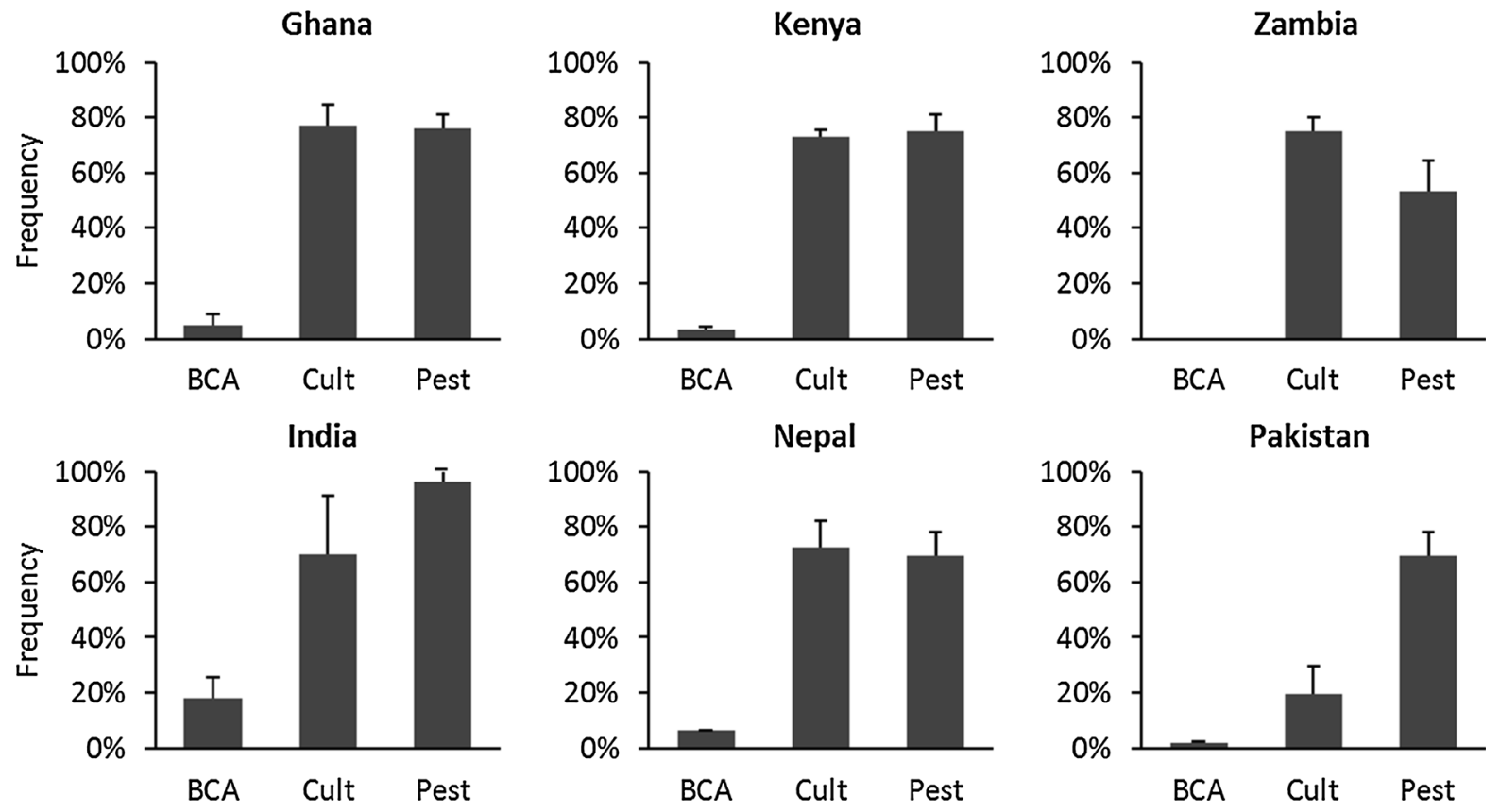

Fig. 1 The frequency of different pest management recommendations for each country's prescription records for all arthropod pests, categorised as biological control agent (BCA), cultural (Cult) and botanical or chemical pesticide (Pest). Each

Nevertheless, our analysis gives an accurate overview of the problems for which farmers seek help at plant clinics, and hence gives a good representation of the problems for which farmers are willing to change their management practices.

BCAs registered for arthropod pest control in the study countries

Only two microbial BCAs were registered in Pakistan, in Zambia and in Ghana, whereas there were nine BCAs (including macrobials) registered in Kenya and in India (Table 1). Further, for many of the arthropod pests most frequently diagnosed at plant clinics, there were no registered BCAs in the study countries, even though potentially suitable ones are commercially available for these pests in other countries (Table 3; Fig. 2). All of the registered BCAs in our study countries were also registered in developed countries for the control of widely distributed pests, which were mostly the same pests diagnosed at plant clinics. Notable exceptions to this are the cocoa stink bug (Bathycoelia thalassina Herrich-Schaeffer, prescription may have more than one management recommendation, so the percentages are not additive. Error bars represent SE

Hemiptera: Pentatomidae) and cocoa stem borer (Eulophonotus myrmeleon Felder, Lepidoptera: Cossidae) in Ghana. Those two pests, which together represent $23.8 \%$ of the pests diagnosed at plant clinics in Ghana, are mainly restricted to West Africa (GBIF 2017; Plantwise 2017), and no BCAs are registered to control them worldwide.

The risks associated with the use of introduced BCAs in augmentative biological control need to be assessed, and new non-indigenous microbial BCAs need to be registered or otherwise authorised (Hoeschle-Zeledon et al. 2013; Sundh and Goettel 2013). The registration process for microbials is normally similar to that for chemical pesticides, whereas macrobials either do not need to be registered or registration is required only for exotic species, depending on the country (Sundh and Goettel 2013). The comprehensive registration processes based on chemical pesticides are not well adapted to microbials, and efforts by regulatory bodies to address the problem may be limited (Chandler et al. 2011; Sundh and Goettel 2013). As a result, the registration process may be excessively long and costly, deterring companies, especially small agri-input suppliers struggling to 


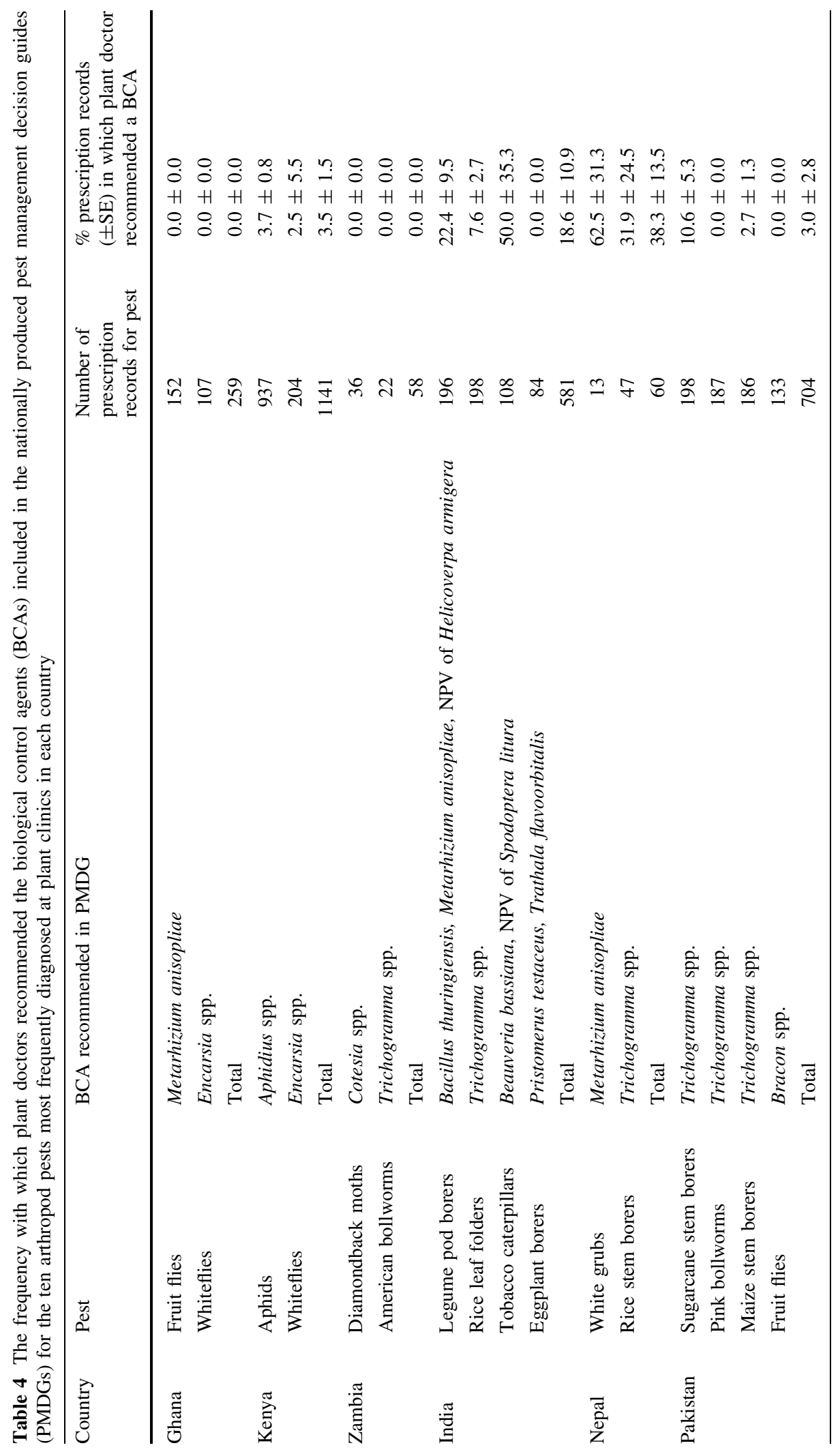


Table 5 The propensity of plant doctors making $\geq 20$ prescription records to make biological control agent (BCA) recommendations

\begin{tabular}{lllll}
\hline Country & $\begin{array}{l}\text { Number of plant } \\
\text { doctors making } \geq 20 \\
\text { prescription records }\end{array}$ & $\begin{array}{l}\text { \% of plant doctors } \\
\text { recommending } \\
\text { BCAs at least once }\end{array}$ & $\begin{array}{l}\text { \% of plant doctors that } \\
\text { include BCAs in } \geq 10 \% \text { of } \\
\text { prescription records }\end{array}$ & $\begin{array}{l}\text { \% of total BCA recommendations made by } \\
\text { the plant doctors that included BCAs } \\
\text { in } \geq 10 \% \text { of prescription records }^{\mathrm{a}}\end{array}$ \\
\hline Ghana & 48 & 52.1 & 14.6 & 62.9 \\
Kenya & 73 & 49.3 & 10.9 & 55.9 \\
Zambia & 6 & 0.0 & 0.0 & Not applicable \\
India & 11 & 54.5 & 36.4 & 97.2 \\
Nepal & 9 & 66.7 & 33.3 & 80.0 \\
Pakistan & 94 & 4.3 & 1.1 & 55.6 \\
\hline
\end{tabular}

${ }^{\text {a }}$ Of total BCA recommendations made by plant doctors making $\geq 20$ prescription records
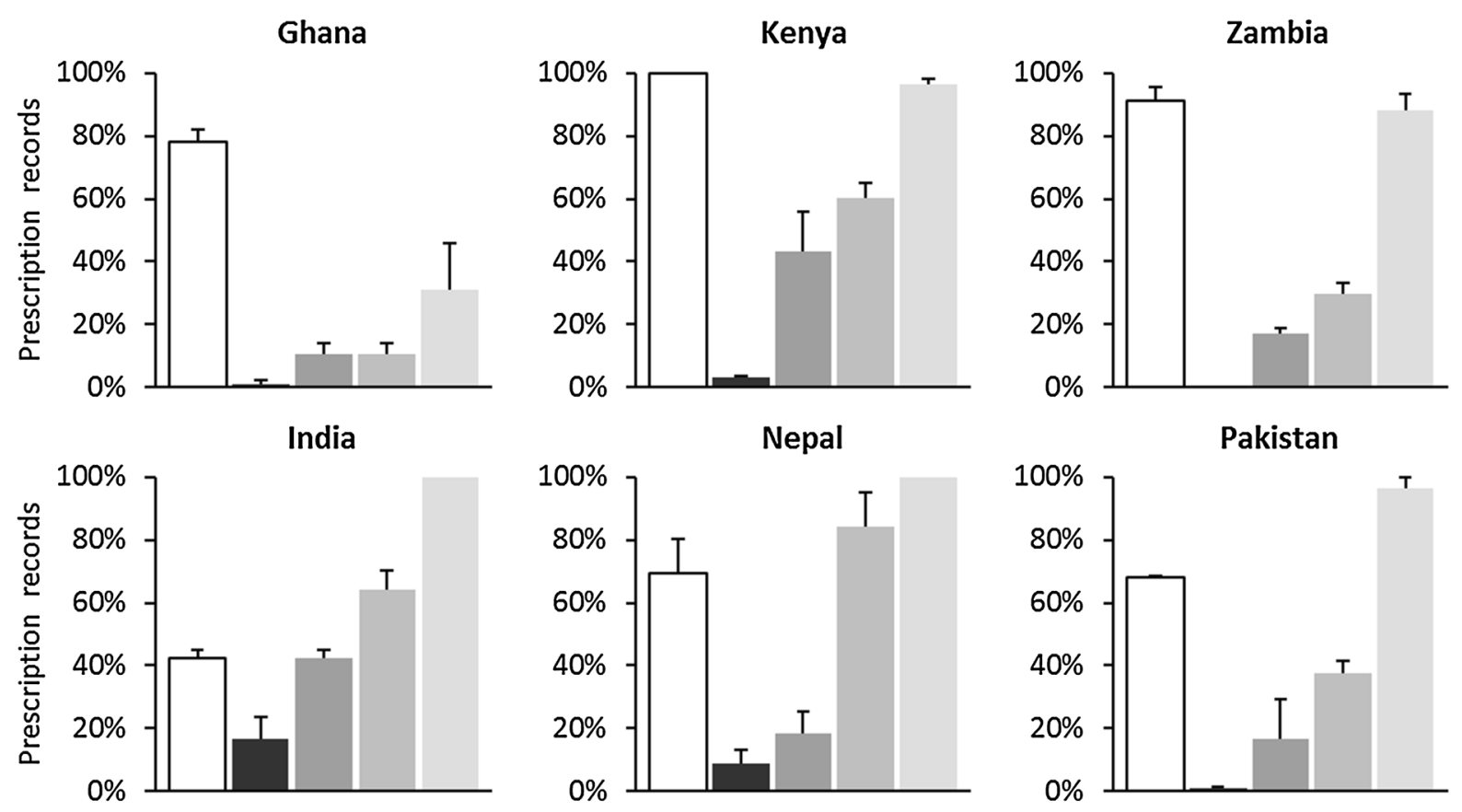

With PMDG available

With a BCA recommended by plant doctors

For which PMDGs have a BCA recommendation

For which a suitable BCA is available at a national level

For which a suitable BCA is commercially available in another country

Fig. 2 Analysis of the barriers and potential to recommend biological control agents (BCAs) in response to plant clinic enquiries for the top ten arthropod pests in each of the study countries: the availability of nationally produced pest management decision guides (PMDGs), the recommendation of BCAs by plant doctors, the recommendation of BCAs in nationally

establish in a niche market (Harman et al. 2010; Sundh and Goettel 2013). Among the study countries, India and Kenya have developed a regulatory pathway produced PMDGs, the availability of a suitable BCA at a national level (BCAs nationally registered and, in the case of macrobials, included in a nationally produced PMDG) and the availability of a suitable BCA in another country. Error bars represent $\mathrm{SE}$

better adapted to BCAs (Hoeschle-Zeledon et al. 2013) and hence a larger number of BCAs are registered in those two countries. 
Accordingly, it would be beneficial if all countries adopt a regulatory pathway that streamlines and facilitates the registration of BCAs. National research programmes will be aware of the pests which farmers bring most often to plant clinics seeking help (Table 3), so that potential BCA solutions for these pests can be prioritised for evaluation. At first examination, if all apparently suitable BCAs were registered in each country (and were available and affordable), then BCA recommendations could be made for nearly all the major pests currently being diagnosed at plant clinics (Fig. 2). However, the absence of biological control solutions for important cocoa pests in Ghana is one obvious gap at present.

Availability of extension material including BCAs

To date, the prioritisation and compilation of PMDGs by national programmes has been largely on the basis of what pest management information was available. From 14 (Nepal) to 28 (Kenya) PMDGs have been compiled for arthropod pests in each of our study countries, and 13.0 (Zambia) to $61.1 \%$ (India) of these had BCA recommendations (Table 2). Analyses such as Table 3, which show the most frequent enquiries at plant clinics, are already being made by national programmes, and are leading to the identification of additional PMDGs that need to be prepared to address pests for which farmers most commonly seek assistance. This in turn may lead to the identification of research gaps that need to be addressed, particularly when new pests, such as T. absoluta, first appear in a country (Cameron et al. 2016).

Appropriate and registered BCAs were not always included in nationally produced PMDGs (Table 4), although this gap was relatively small compared to other factors shown in Fig. 2. We have yet to investigate in detail why this gap exists. However, PMDG authors and editors learn to include only recommendations which are safe, effective and practical. Products that are considered too costly or unavailable are deemed impractical and are not included in PMDGs (Cameron et al. 2016). Often there are no data on the efficacy of BCAs under local conditions for a particular pest/crop combination to support their inclusion as a recommendation.

Insufficient technical support and limited access to extension material are pointed out as major barriers to the uptake of IPM in developing countries (Parsa et al.
2014). Interactive communication, such as the conversation between farmers and extension staff which takes place at plant clinics, is an important factor contributing to the uptake of new technologies. Appropriate extension material, including visual support, contributes to a successful uptake (Anandajayasekeram et al. 2008). To improve the current situation, a country-specific analysis of each gap should identify key constraints. Extension services and Plantwise in particular, should develop extension materials which cover most if not all the major pests and should include all the appropriate BCAs registered to control them. Research gaps should be addressed by the national research system in order to evaluate the efficacy of BCAs.

BCA recommendations made by plant doctors

Plant doctors' use of BCA recommendations included in nationally produced PMDGs varied among countries (Table 4) and among plant doctors (Table 5). Overall, chemical control was still largely dominant in the recommendations made by plant doctors, and BCA recommendations were generally uncommon (Fig. 1). However, this was not uniform. For example in Nepal, M. anisopliae is regularly recommended for white grub (62.5\%), as were Trichogramma spp. for rice stem borer (31.9\%) (Table 4), although across all arthropod prescriptions the rate was lower (6.2\%) (Fig. 1). BCAs were relatively frequently included across all arthropod prescription forms in India (18.2\%) (Fig. 1) particularly the use of microbials for control of legume pod borers, and tobacco caterpillars (Spodoptera litura Fabricius, Lepidoptera: Noctuidae) (Table 4). A subsequent analysis indicated that the frequency of BCA recommendations may vary among different regions of a country. This could merit further analyses.

For the top ten arthropod pests in each country, our analysis in Fig. 2 shows that $0-16.7 \%$ of prescription records included a BCA recommendation, suggested in nationally produced PMDGs whenever possible. This could rise to $10.4-42.2 \%$. Why do plant doctors not recommend more BCAs? Extra knowledge and lack of knowledge amongst plant doctors may both play a role. We have highlighted that availability and price putatively play major roles in whether BCAs are included in PMDGs, and these factors might also affect whether plant doctors include BCAs in their recommendations. Limited access to biopesticides is 
reported to be a major barrier to adoption of IPM by farmers in developing countries (Jenkins and Vos 2000; Parsa et al. 2014; Williamson and Ali 2000), or their price is reported to be too high for small scale farmers (Harman et al. 2010). Discussion with locally based Plantwise staff confirmed that BCAs were often locally unavailable, and that when they were available, prices may have been prohibitively expensive. In Zambia, no BCAs were available (I. Nthengha, pers. comm. 2016) in spite of two being registered. In Ghana, only Bypel (a combination of B. thuringiensis and of the granulosis virus of Pieris rapae L., Lepidoptera: Pieridae) was widely available but it was very expensive, about three times the price of a relatively cheap insecticide, cypermethrin (B. Oppong-Mensah, pers. comm. 2016). However, a wide range of BCAs was available at relatively affordable prices in Tamil Nadu, India, though only close to urban areas. The price of a Trichogramma spp. treatment was similar to the price of a treatment with cypermethrin, while $M$. anisopliae, B. bassiana and $B$. thuringiensis were reported to be 21,71 and $71 \%$ more expensive, respectively (G. Rajendran, pers. comm. 2016). In India, Trichogramma spp. is reported to be the most cost effective control method for rice stem borers (Bhushan et al. 2012; Raj and Hill 2000), but in most cases BCAs are more expensive than chemical pesticides. Thus, it may often be the case that plant doctors do not recommend BCAs because they know they are not available or too expensive for farmers.

Pricing and distribution issues should be addressed by agri-input suppliers, possibly with support from the government. The data we analysed show that pests for which a BCA is nationally registered may be very abundant in some regions, e.g. aphids represent $34.5 \%$ of the arthropod pests diagnosed at plant clinics in the Rift region of Kenya. This underlines that markets for selected BCAs may be locally large and that there is an opportunity for agri-input suppliers to provide BCAs. Linkages among stakeholders, including agri-input suppliers and retailers, are already being assessed by the Plantwise programme (Plantwise 2016a) and should be further encouraged so that recommended BCAs are available where needed at an affordable price.

A lack of knowledge about the existence, availability and efficacy of BCAs amongst extension staff including plant doctors is also possible. Within each country a limited number of plant doctors made most of the BCA recommendations while a significant proportion of plant doctors never recommended BCAs (Table 5). This knowledge barrier could be tackled by adjusting training curricula for extension staff and targeted training to promote the use of BCAs. Extension staff needs to be aware of the advantages of BCAs over synthetic pesticides, and receive information on the availability of locally registered BCAs and how to use them. Moreover, partner countries should ensure that extension material is broadly available and distributed to all extension staff.

Institutional and private sector support could also explain some of the variation in uptake of BCAs by extension staff among and within countries. The lack of adoption incentives has been identified as a major barrier to the adoption of IPM in developing countries (Parsa et al. 2014). In India, BCA production and uptake by extension staff and farmers are supported by the state (Hoeschle-Zeledon et al. 2013; Raj and Hill 2000). As a result, extension workers are more familiar with BCAs, and BCAs are more widely available and affordable. Linkages among stakeholders are reported to be a major factor contributing to the uptake of new technologies by farmers (Anandajayasekeram et al. 2008). A positive impact of the private sector on the uptake of BCAs by farmers in India has been reported by Raj and Hill (2000). In Pakistan, the highest BCA uptake rate by plant doctors was for Trichogramma spp. for control of sugarcane stem borers. This approach is supported by sugar mills (Biocontrol Files 2008), confirming that participation of third parties contributes to the adoption of BCAs. Thus, government agencies and other stakeholders should coordinate their efforts and adopt proactive attitudes in order to promote the adoption of BCAs.

\section{Farmer actions}

We have not considered how farmers use the advice they are given at plant clinics. BCAs are normally recommended by plant doctors alongside other management options. Plant doctors learn to give comprehensive recommendations based on an IPM approach. Recommendations should include advice on preventive measures, pest monitoring, cultural control, biological control and chemical control, when justified (Taylor 2015). One of the benefits of this approach is 
that it raises awareness among plant doctors and farmers of good farming practices, including alternatives to chemical control and of the ecological services that result from preservation of biodiversity in farmland. It is reported that $89 \%$ of the farmers visiting a plant clinic follow the advice they receive (Plantwise 2016a). However, often farmers must make a choice from among the recommendations given by plant doctors, and the way they do this is not clear. Farmers tend to avoid risk which is reported to hold back the uptake of BCA in developed countries (Chandler et al. 2011; Marrone 2007). Further studies are required to appraise the use of BCAs by small scale farmers in low- to lower- middle- income countries. Botanical or chemical control measures may not be compatible with BCAs, especially macrobials, and we have no data on how well this is explained by plant doctors and understood by farmers. Moreover, BCAs need not only to be mentioned by extension staff, but their correct use should also be explained in detail. These aspects will be examined in future Plantwise studies.

Our analysis focused on three African and three Asian countries. The situation may be considerably different in other regions or countries which were not included in the study. Nevertheless, the countries included differ substantially, and our analysis gives a broad overview of some of the situations that can be encountered in low- to lower- middle- income countries. Extension services have the potential to actively contribute to the promotion of BCAs. However, in the case of the Plantwise programme, there is considerable scope to increase the number of BCA recommendations by extension staff in all countries, although less so in Ghana, where BCA options are not available for some of the pests most frequently diagnosed at plant clinics. In spite of the large amount of extension material already developed by the Plantwise programme, lack of extension material including BCA recommendations and lack of knowledge of BCAs and their use among extension staff were identified as internal barriers. Limited availability of registered products, lack of incentives for the production and use of BCAs, limited availability in agri-input supplier outlets and high prices were identified as major external barriers to the uptake of BCAs by NEPs. Extension material and advice to farmers should aim to include, when appropriate, adequate BCA recommendations for all major pests. In order to further support the uptake of BCAs by
NEPs and extension services in general, and hence foster their uptake by farmers, countries need a wider range of registered, available and affordable BCAs. This can be facilitated by developing regulatory pathways appropriate for BCAs. Government and other stakeholder support for the production and use of BCAs will further contribute to their uptake. Through the national documentation of plant doctor diagnoses and recommendations as part of the Plantwise programme, countries can now identify priority areas where the national plant health system can reduce some of the most important barriers to on-farm use of augmentative biological control options against the most important pests.

Acknowledgements We would like to thank all the extension service providers in their function of plant doctors for gathering the plant clinic data and the in-country plant clinic data managers for managing and uploading the data. We are grateful to the Plant Protection and Regulatory Services Directorate, Ministry of Food and Agriculture, Ghana; the Ministry of Agriculture, Livestock and Fisheries, Kenya; the MS Swaminathan Research Foundation (MSSRF), India; D. Ram Sharma, Plant Protection Directorate, Ministry of Agricultural Development, Nepal; the Directorates of Agriculture Extension of Punjab and Sindh provinces, Pakistan; and C. Sondashi, Ministry of Agriculture, Zambia for their key role in the successful implementation of the Plantwise programme and for making the plant clinic data available for this study. We thank B. Oppong-Mensah, CABI, Ghana; G. Sudhakar and R. Rajkumar, both MSSRF, India; and I. Nthenga, Zambia Agriculture Research Institute, Zambia, for the collection of information on price and availability of biological control agents. We thank the Plantwise Knowledge Bank team in the UK and our national content development partners for providing access to the Pest Management Decision Guides required for the analysis. We would also like to acknowledge the CABI regional and country coordinators for facilitating contacts with in-country partners and providing information and data. This study was made possible through the financial support to the Plantwise programme by the Department for International Development (DfID, UK), the Swiss Agency for Development and Cooperation (SDC, Switzerland), the European Commission's Directorate General for International Cooperation and Development (DG DEVCO), the Directorate General for International Cooperation (DGIS, Netherlands), the International Fund for Agricultural Development (IFAD), Irish Aid (Ireland) and the Australian Centre for International Agricultural Research (ACIAR, Australia).

Open Access This article is distributed under the terms of the Creative Commons Attribution 4.0 International License (http:// creativecommons.org/licenses/by/4.0/), which permits unrestricted use, distribution, and reproduction in any medium, provided you give appropriate credit to the original author(s) and the source, provide a link to the Creative Commons license, and indicate if changes were made. 


\section{References}

Abhilash PC, Singh N (2009) Pesticide use and application: an Indian scenario. J Hazard Mater 165(1-3):1-12

Anandajayasekeram P, Puskur R, Workneh S, Hoekstra D (2008) Concepts and practices in agricultural extension in developing countries: a source book. International Livestock Research Institute, IPMS Ethiopia, Ethiopia

Bale JS, van Lenteren JC, Bigler F (2008) Biological control and sustainable food production. Philos Trans R Soc Lond B Biol Sci 363(1492):761-776

Bhushan S, Singh RP, Shanker R (2012) Biopesticidal management of yellow stem borer (Scirpophaga incertulas) in rice. Bioscan 7(2):317-319

Biocontrol Files (2008) Biocontrol—a quick global tour: Global biocontrol highlights. Biocontrol Files-Canada's bulletin on ecological pest management 13:1-5

Cameron K, Somachandra KP, Curry CN, Jenner WH, Hobbs SLA (2016) Delivering actionable plant health knowledge to smallholder farmers through the Plantwise program. J Agric Food Inf 17(4):212-229

Chandler D, Bailey AS, Tatchell GM, Davidson G, Greaves J, Grant WP (2011) The development, regulation and use of biopesticides for integrated pest management. Philos Trans R Soc Lond B Biol Sci 366(1573):1987-1998

CIBRC (2016a) Biopesticides registrants. Central Insecticides Board and Registration Comitee-India. http://www.cibrc. nic.in. Accessed 27 Oct 2016

CIBRC (2016b) Major uses of pesticides: biopesticides. Central Insecticides Board and Registration Comitee-India. http://www.cibrc.nic.in. Accessed 27 Oct 2016

Cock MJW, van Lenteren JC, Brodeur J, Barratt BIP, Bigler F, Bolckmans K, Cônsoli FL, Haas F, Mason PG, Parra JRP (2010) Do new access and benefit sharing procedures under the convention on biological diversity threaten the future of biological control? BioControl 55(2):199-218

Cock MJW, Biesmeijer JC, Cannon RJC, Gerard PJ, Gillespie D, Jiménez JJ, Lavelle PM, Raina SK (2012) The positive contribution of invertebrates to sustainable agriculture and food security. CAB Rev Perspect Agric Vet Sci Nutri Nat Resour 7(43): 1-27

Danielsen S, Matsiko FB (2016) Using a plant health system framework to assess plant clinic performance in Uganda. Food Sec 8(2):345-359

DPP (2016) List of registered pesticides. Department of Plant Protection-Pakistan. http://plantprotection.gov.pk/pestici de-registration. Accessed 8 Jul 2016

GBIF (2017) Distributions for Eulophonotus myrmeleon. GBIF. http://www.gbif.org/species/124332293/distributions. Accessed 08 Feb 2017

Glare T, Caradus J, Gelernter W, Jackson T, Keyhani N, Kohl J, Marrone P, Morin L, Stewart A (2012) Have biopesticides come of age? Trends Biotechnol 30(5):250-258

Harman GE, Obregón MA, Samuels GJ, Lorito M (2010) Changing models for commercialization and implementation of biocontrol in the developing and the developed World. Plant Dis 94(8):928-939

Harper DR (2013) Biological control by microorganisms. In: eLS. Available via Wiley Online Library. doi: 10.1002/ 9780470015902.a0000344.pub3
Hoeschle-Zeledon I, Neuenschwander P, Kumar L (2013) Regulatory challenges for biological control. SP-IPM Secretariat, International Institute of Tropical Agriculture (IITA), Ibadan

Homologa (2016) The global crop protection products database. Homologa. http://www.homologa-new.com/pls/apex/f?p= 550:1. Accessed 19 Oct 2016

IOBC (2016) The IOBC green and yellow list approach goes global with plantwise. International Organization for Biological Control. http://www.iobc-global.org/news_20160 121_Plantwise.html. Accessed 18 Oct 2016

Jenkins NE, Vos J (2000) Delivery of biocontrol technologies to IPM farmers: Vietnam. In: Dent DR, Gopalan H (eds) UNEP/CABI Critical issues case studies. UNEP, Nairobi

Koul O (2011) Microbial biopesticides: opportunities and challenges. CAB Rev 6:1-26

Lewis WJ, van Lenteren JC, Phatak SC, Tumlinson JH (1997) A total system approach to sustainable pest management. Proc Natl Acad Sci 94(23):12243-12248

Marrone P (2007) Barriers to adoption of biological control agents and biological pesticides. CAB Rev Perspect Agric Vet Sci Nutri Nat Resour 2(051)

Olson S (2015) An analysis of the biopesticide market now and where it is going. Outlook Pest Man 26(5):203-206

Parsa S, Morse S, Bonifacio A, Chancellor TCB, Condori B, Crespo-Perez V, Hobbs SLA, Kroschel J, Ba MN, Rebaudo F, Sherwood SG, Vanek SJ, Faye E, Herrera MA, Dangles O (2014) Obstacles to integrated pest management adoption in developing countries. Proc Natl Acad Sci 111(10): 3889-3894

PCPB (2015) Pest control products registered for use in Kenya, 10th edn. Pest Control Products Board-Kenya. http://pcpb. or.ke/cropproductsviewform.php. Accessed 30 Sep 2016

Plantwise (2016a) Plantwise annual report 2015. CABI. https:// www.plantwise.org/Uploads/Plantwise/Plantwise\% 20Annual\%20Report\%202015.pdf. Accessed 11 Nov 2016

Plantwise (2016b) About Plantwise. CABI. http://www. plantwise.org/about-plantwise. Accessed 15 Nov 2016

Plantwise (2017) Plantwise knowledge bank. CABI. http:// www.plantwise.org/KnowledgeBank/PWMap.aspx. Accessed 08 Feb 2017

PRMD (2015) Updated registered pesticide list. Pesticide Registration \& Management Division-Nepal. http://www. prmd.gov.np/downloadfile/pesticide_1475561059.pdf. Accessed 27 Oct 2016

Raj DA, Hill MG (2000) Delivery of biocontrol technologies to IPM farmers: India. In: Dent DR, Gopalan H (eds) UNEP/ CABI Critical issues case studies. UNEP, Nairobi

Sundh I, Goettel MS (2013) Regulating biocontrol agents: a historical perspective and a critical examination comparing microbial and macrobial agents. BioControl 58(5):575593

Taylor P (2015) Plantwise diagnostic field guide: a tool to diagnose crop problems and make recommendations for their management. CABI, Wallingford

Thakore Y (2006) The biopesticide market for global agricultural use. Ind Biotechnol 2(3):194-208

van Lenteren JC (2012) The state of commercial augmentative biological control: plenty of natural enemies, but a frustrating lack of uptake. BioControl 57(1):1-20 
van Lenteren JC, Bolckmans K, Köhl J, Ravensberg WJ, Urbaneja A (2017) Biological control using invertebrates and microorganisms: plenty of new opportunities. Bio Control. doi:10.1007/s10526-017-9801-4

Williamson S, Ali B (2000) Delivery of biocontrol technologies to IPM farmers: Nicaragua. In: Dent DR, Gopalan H (eds) UNEP/CABI Critical issues case studies. UNEP, Nairobi

Julien Dougoud is a CABI associate consultant. He has a background in agronomy and interest in sustainable pest management.
Dr Matthew Cock is CABI's chief scientist and an honorary member of the International Organization for Biological Control.

Dr Steve Edgington is a senior scientist within the biopesticide research and development team at CABI.

Dr Ulrich Kuhlmann is CABI's executive director, Global Operations, responsible for fostering collaborations between $\mathrm{CABI}$ centres and international research and development. 